\title{
Endoparasitic mites of the genus Endotrombicula Ewing, 1931 (Acari: Prostigmata: Parasitengona: Trombiculidae) from African and Madagascan anurans, with description of a new species
}

\author{
Andreas Wohltmann ${ }^{1}$, Louis du Preez ${ }^{2}$, Mark-Oliver Rödel $^{3}$, Jörn Köhler $^{4}$ and Miguel Vences ${ }^{5}$ \\ ${ }^{1}$ Findorffstr. 11, D-27721 Ritterhude, Germany; \\ ${ }^{2}$ School of Environmental Sciences and Development, Potchefstroom Campus, North-West University, Private Bag X6001, \\ Potchefstroom 2520, South Africa; \\ ${ }^{3}$ University of Würzburg, Department of Animal Ecology and Tropical Biology, Biocenter, Am Hubland, D-97074 Würzburg, \\ Germany; \\ ${ }^{4}$ Department of Natural History - Zoology, Hessisches Landesmuseum Darmstadt, Friedensplatz 1, D-64283 Darmstadt, \\ Germany; \\ ${ }^{5}$ Zoological Institute, Technical University of Braunschweig, Spielmannstr. 8, D-38160 Braunschweig, Germany
}

Key words: Amphibia, Anura, Mantellidae, Ptychadenidae, endoparasites, Endotrombicula ptychadenae, new species, Africa, Madagascar

\begin{abstract}
A sample of over 6,000 specimens of frogs belonging to about 120 species of all families occurring in West Africa and Madagascar were screened for parasitic mites. Three species of Endotrombicula Ewing, 1931 were found in representatives of two African and two Madagascan frog families. All Trombiculidae found in African frogs belonged to Endotrombicula pillersi (Sambon, 1928), whereas in Madagascar E. madagascariensis (Sambon, 1928) and E. ptychadenae sp. n. were sampled. These three species are described, data about their parasitic associations are provided, and their zoogeographical distribution is discussed. Only those frog species that spend a considerable time in terrestrial ground habitats were parasitized; neither arboreal nor strictly aquatic frogs were infected. The geographic distribution of Endotrombicula, restricted to Africa, the Arabian Peninsula and Madagascar, suggests that these mites invaded Madagascar from the African continent. This is supported by the observation that the ancestors of Ptychadena mascareniensis (Duméril et Bibron) (Ptychadenidae), the host of E. ptychadenae, colonized Madagascar from the African continent quite recently, possibly accompanied by its Endotrombicula parasites.
\end{abstract}

The phylogenetic relationships of amphibians have recently attracted much attention (e.g., Frost et al. 2006) and are often explained largely in terms of vicariance during the break-ups of the supercontinents Pangaea and Gondwana (Roelants and Bossuyt 2005). However, recent evidence suggests that amphibians are capable to disperse over marine barriers (Vences et al. 2003, 2004, Measey et al. 2006). Although current assembling of comprehensive molecular data sets leads to fast progress in the understanding of phylogenetic and biogeographic relationships among amphibians, independent data are needed to validate these often surprising results.

In many cases, occurrence and phylogenies of parasites mirror those of their hosts and can therefore provide crucial evidence on their hosts' relationships; e.g., Bentz et al. (2001) for polystome plathelminths in amphibians. A further group of parasites regularly found in amphibians are mites, but systematic studies on these are relatively rare and mostly inaccurate. During recent herpetological field work in West Africa and Madagascar a number of frogs turned out to be infested with mite larvae of the genus Endotrombicula Ewing, 1931.
Morphological analysis of the mites revealed that they belong to three distinct species. Because published descriptions did not allow unambiguous determination, we herein provide redescriptions of two known and the first description of one hitherto unknown species. Moreover, we discuss the putative geographic origin of $E n$ dotrombicula spp. in Madagascar.

\section{MATERIALS AND METHODS}

Specimens of Endotrombicula were removed from hosts collected at various localities in Africa and Madagascar from August to April in 1992-2006. Collected frog specimens were anaesthetized in chlorobutanol solution, fixed in $95 \%$ and preserved in $70 \%$ ethanol.

After removal from their hosts, mite larvae were cleared in hot 1-mol $\mathrm{KOH}$ and subsequently in lactic acid, and finally mounted in polyvinyl-lactophenol. Drawings and measurements were done using an Olympus $\mathrm{BH} 2$ microscope equipped with differential interference phase-contrast and camera lucida. Measurements are given in $\mu \mathrm{m}$, data in parentheses are lengths unless otherwise stated. For morphological terminology and abbreviations see Robaux (1974) and Wohlt- 
mann et al. (2006a). Museum abbreviations used are as follows: BMNH - British Museum of Natural History, London, Great Britain; PaU - Institute of Parasitology, Academy of Sciences of the Czech Republic, České Budějovice; SMNS Staatliches Museum für Naturkunde Stuttgart, Germany; UADBA - Université d'Antananarivo, Département de Biologie Animale, Madagascar; ZFMK - Zoologisches Forschungsmuseum Alexander Koenig, Bonn, Germany; ZMH - Biozentrum Grindel und Zoologisches Museum (formerly known as "Zoologisches Institut und Museum der Universität Hamburg"), Hamburg, Germany; ZSM - Zoologische Staatssammlung München, Germany. Frog vouchers are deposited at SMNS, UADBA, ZFMK, ZSM, and the research collection of M.-O. Rödel at the Würzburg University. Frog specimens to be catalogued in UADBA and ZSM are herein reported with their preliminary field numbers: FGZC - Frank Glaw Zoological Collection, and ZCMV - Zoological Collection of Miguel Vences.

\section{RESULTS}

Endotrombicula pillersi (Sambon, 1928)

Fig. 1

1928 Schoengastia pillersi, Sambon, Ann. Trop. Med. Parasitol. 22: 122.

1954 Endotrombicula pillersi, Radford, Fieldiana 34 (28): 307.

1999 Endotrombicula pillersi, Spieler and Linsenmair, Am. Midl. Nat. 142 (1): 153.

Description. Larva $(n=21)$. Range of idiosoma: 150 length $\times 100$ width to 610 length $\times 380$ width $(n=60$, not mounted or squeezed). Gnathosoma (Fig. 1C): Cheliceral claw with three prominent teeth dorsally, outer side laterally with prominent tooth directed backwardly. Dorso-laterally at anterior part of gnathosoma a pair of smooth, pointed deutorostral setae (os) (23-27), ventrally near base of gnathosoma a pair of tritorostral setae (bs) (30-39), each with 7-9 setules. No protorostrals, no supracoxal setae seen. Palp femur with serrate seta (19-24), palp genu with shorter serrate seta (9-16) in dorsal position. Palp tibia with two smooth setae dorsally plus one seta with 5-8 prominent setules laterally. Palp tarsus with 7 setulose setae, proximal solenidium $\omega$ and distal eupathidium $\zeta$. Odontus distally divided into two lateral claws and a weaker median claw. Idiosoma, dorsum (Fig. 1A): Scutum (Fig. 1B) pentagonal with two pairs of serrate setae (AL, PL) unpaired median seta (AM) anteriorly and paired trichobothria. Sensilla (Sens) smooth, distally globular (diameter 14-16). Laterally of scutum paired ocular sclerites $(10-13 \times 21-$ $24)$. On each ocular sclerite 1-2 eyes, in some specimens two eyes on one side, single lens on the other. Posterior eye lens slightly smaller in diameter (5-6) than anterior lens (8-10). Posterior to scutum 30 barbed setae (35-45) arranged in rows: C ( $\left.\mathrm{c}_{1-5}\right), \mathrm{D}\left(\mathrm{d}_{1-3}\right), \mathrm{E}\left(\mathrm{e}_{1-}\right.$ 3), F ( $\left.f_{1-3}\right) H\left(h_{1}\right)$. Idiosoma, venter (Fig. 1A): Paired Claparède's organs laterally between coxae I/II. Coxa I with setulose seta $1 \mathrm{~b}(33-35)$; seta $1 \mathrm{a}(31-34)$ barbed, located medially outside coxal plate. Coxa II with setulose seta 2 b (25-27); coxa III with setulose seta 3 b (33$35)$. One pair of barbed intercoxal setae 3a (32-36) medially of coxae III. Posterior to level of coxae III about 24 setae (length 22-36) around the unsclerotized anal opening (about 20 long). Legs (Fig. 1D): Segmentation formula: 7-7-7, each femur I-III completely divided into basi- and telofemur. Pretarsus of legs I-III each with paired claws and claw-like empodium; claws and empodium smooth, without splinters. Setal patterns in Table 1, morphometric data in Table 2.

Postlarval instars unknown.

H o s t s : Anura. Petropedetidae: Petropedetes natator Boulenger (3 frogs, 45 mites, Guinea). Phrynobatrachidae: Phrynobatrachus accraensis (Ahl) $(1,15$, Ivory Coast, Taï National Park); Phrynobatrachus alleni Parker (2, 3, Ghana, Ivory Coast, Taï National Park); Phrynobatrachus tokba (Chabanaud) (2, 14, Guinea); Phrynobatrachus calcaratus (Peters) $(9,90$, Ghana, Ivory Coast); Phrynobatrachus francisci Boulenger (2, 36, Benin, Ivory Coast, Taï National Park); Phrynobatrachus phyllophilus Rödel et Ernst (3, 39, Guinea); Phrynobatrachus plicatus (Günther) (1, 18, Ivory Coast, Taï National Park); Phrynobatrachus villiersi Guibé (1, 16, Ivory Coast, Taï National Park). Data on slides of BMNH material: Holotype E. pillersi: Phrynobatrachus natalensis (White Volta Valley Ashanti, Bawhu Navrango, upper reaches); specimen no. 1952-924-60: Phrynobatrachus acridoides (part of original slot, origin: Black Volta Valley, Vanbor Burley bwi, Ashanti); specimens no. 1952-9-24-56, no. 1952-9-24-57 and no. 1952-9-24-59: Phrynobatrachus natalensis (Gold Coast, Africa).

Material used for redescription: Specimens on slides from BMNH (holotype of E. pillersi and specimens 1952-9-24-60, 1952-9-24-56, 1952-9-24-57, 1952-924-59) were not suitable for redescription because insufficiently cleared; moreover, their legs are partly lost or shrivelled. Therefore the present redescription is based on 21 specimens from all the above mentioned hosts and regions. Vouchers deposited at BMNH: specimen TI271102L23a ex $P$. natator, Guinea, Simandou, Pic de Fon area, $08^{\circ} 31^{\prime} 86 \mathrm{~N}, 08^{\circ} 54^{\prime} 36 \mathrm{~W}, 27$ November 2002 and specimen TI 000902L25a ex P. alleni, Ivory Coast, Taï National Park, September 2002. Vouchers deposited at ZMH: specimen TI221103L14b ex P. phyllophilus and TI221103L2e ex P. alleni; both Guinea, Diécké classified forest, $07^{\circ} 35^{\prime} 46 \mathrm{~N}, 08^{\circ} 52^{\prime} 18 \mathrm{~W}$, November 2003 . Vouchers deposited at PaU: TI160904L21a, b ex $P$. calcaratus, Ivory Coast, Lamto, $06^{\circ} 13^{\prime} 05 \mathrm{~N}, 05^{\circ} 01^{\prime} 49 \mathrm{~W}, 17$ September 2004, no. PAU 2018. 

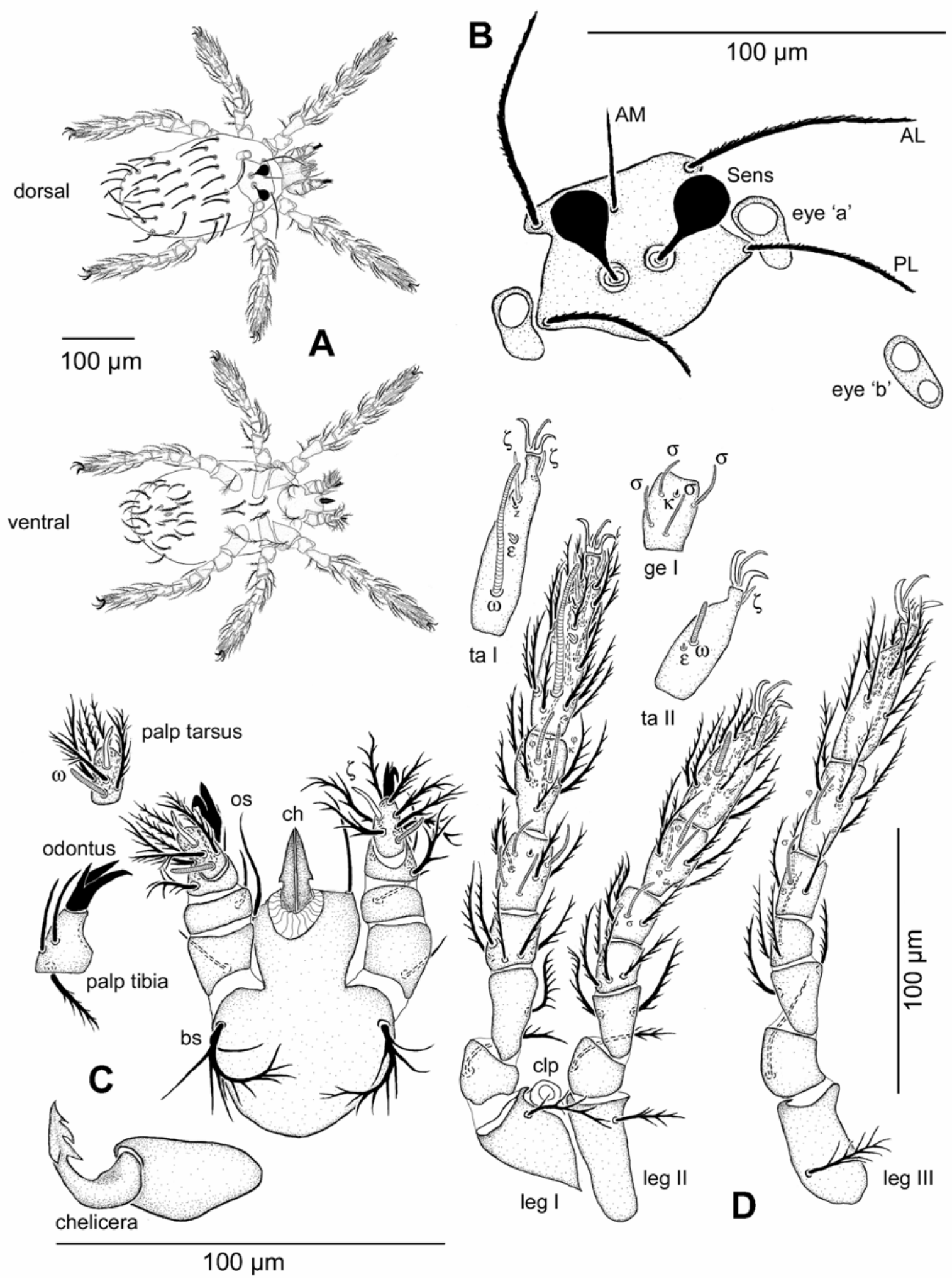

Fig. 1. Endotrombicula pillersi, larva. A - Dorsal and ventral habitus of a moderately engorged larva. B - Scutum and ocular sclerite; AM - anterior median seta; AL - anterior lateral setae; PL - posterior lateral seta; Sens - sensillum of trichobothrium; eye ' $a$ ', eye ' $b$ ' - alternative character states of the ocular plate carrying one or two eye lenses. C - Gnathosoma, ventral view; details of palp tarsus in ventral view, of palp tibia in dorsolateral view, chelicera in lateral view; bs - tritorostral seta; ch - tip of chelicera; odontus - palp tibial claw; os - deutorostral seta; $\omega$ - solenidion on palp tarsus; $\zeta$ - eupathidium on palp tarsus. D Legs; clp - Claparède's organ. Only specialised setae shown in details of tarsus I (ta I), genu I (ge I) and tarsus II (ta II). For seta abbreviations see text. 
Table 1. Leg setae of Endotrombicula larvae. For seta abbreviations see Fig. 1; B - nonspecialised setulose seta, N - nonspecialised nude seta. Data in parentheses: exceptional number of setae found on 1-2 legs in all investigated specimens.

\begin{tabular}{lccc}
\hline & $\begin{array}{c}\text { E. pillersi } \\
(\mathrm{n}=21)\end{array}$ & $\begin{array}{c}\text { E. madagascariensis } \\
(\mathrm{n}=15)\end{array}$ & $\begin{array}{c}\text { E. ptychadenae sp. } \mathrm{n} . \\
(\mathrm{n}=12)\end{array}$ \\
\hline Palp femur & $1 \mathrm{~B}$ & $1 \mathrm{~B}$ & $1 \mathrm{~B}$ \\
Palp genu & $1 \mathrm{~B}$ & $1 \mathrm{~B}$ & $1 \mathrm{~B}$ \\
Palp tibia (excl. odontus) & $2 \mathrm{~N} 1 \mathrm{~B}$ & $2 \mathrm{~N} 1 \mathrm{~B}$ & $1 \mathrm{~N} 2 \mathrm{~B}$ \\
Palp tarsus & $7(8) \mathrm{B}, 1 \omega, 1 \zeta$ & $7 \mathrm{~B}, 1 \omega, 1 \zeta$ & $7 \mathrm{~B}, 1 \omega, 1 \zeta$ \\
Coxa I & $1 \mathrm{~B}$ & $1 \mathrm{~B}$ & $1 \mathrm{~B}$ \\
Trochanter I & $1 \mathrm{~B}$ & $1 \mathrm{~B}$ & $1 \mathrm{~B}$ \\
Basifemur I & $1 \mathrm{~B}$ & $1 \mathrm{~B}$ & $1 \mathrm{~B}$ \\
Telofemur I & $5 \mathrm{~B}$ & $5 \mathrm{~B}$ & $5 \mathrm{~B}$ \\
Genu I & $4(3) \mathrm{B}, 4 \sigma, 1 \kappa$ & $4 \mathrm{~B}, 3 \sigma, 1 \kappa$ & $4 \mathrm{~B}, 6(4-9) \sigma, 1 \kappa$ \\
Tibia I & $8 \mathrm{~B}, 2 \varphi, 1 \kappa$ & $8 \mathrm{~B}, 2 \varphi, 1 \kappa$ & $8 \mathrm{~B}, 2 \varphi, 1 \kappa$ \\
Tarsus I & $19-24 \mathrm{~B}, 1 \omega, 1 \varepsilon, 2 \zeta, 1 z$ & $16-18 \mathrm{~B}, 1 \omega, 1 \varepsilon, 2 \zeta, 1 z$ & $18-20 \mathrm{~B}, 1 \omega, 1 \varepsilon, 2 \zeta, 1 z$ \\
Coxa II & $1 \mathrm{~B}$ & $1 \mathrm{~B}$ & $1 \mathrm{~B}$ \\
Trochanter II & $1 \mathrm{~B}$ & $1 \mathrm{~B}$ & $1 \mathrm{~B}$ \\
Basifemur II & $2 \mathrm{~B}$ & $2 \mathrm{~B}$ & $2 \mathrm{~B}$ \\
Telofemur II & $4 \mathrm{~B}$ & $4 \mathrm{~B}$ & $4 \mathrm{~B}$ \\
Genu II & $3 \mathrm{~B}, 1(2) \sigma$ & $3 \mathrm{~B}, 1 \sigma$ & $3 \mathrm{~B}, 1 \sigma$ \\
Tibia II & $6 \mathrm{~B}, 2(1) \varphi$ & $6 \mathrm{~B}, 2 \varphi$ & $6 \mathrm{~B}, 2 \varphi$ \\
Tarsus II & $14 \mathrm{~B}, 1 \omega, 1 \varepsilon, 1 \zeta$ & $13-14 \mathrm{~B}, 1 \omega, 1 \varepsilon, 1 \zeta$ & $13-14 \mathrm{~B}, 1 \omega, 1 \varepsilon, 1 \zeta$ \\
Coxa III & $1 \mathrm{~B}$ & $1 \mathrm{~B}$ & $1 \mathrm{~B}$ \\
Trochanter III & $1 \mathrm{~B}$ & $1 \mathrm{~B}$ & $1 \mathrm{~B}$ \\
Basifemur III & $2 \mathrm{~B}$ & $2 \mathrm{~B}$ & $2 \mathrm{~B}$ \\
Telofemur III & $3 \mathrm{~B}$ & $3 \mathrm{~B}$ & $3 \mathrm{~B}$ \\
Genu III & $3 \mathrm{~B}, 1 \sigma$ & $3 \mathrm{~B}, 1 \sigma$ & $3 \mathrm{~B}, 1 \sigma$ \\
Tibia III & $6 \mathrm{~B}, 1 \varphi$ & $6 \mathrm{~B}, 1 \varphi$ & $6 \mathrm{~B}, 1 \omega$ \\
Tarsus III & $13-15 \mathrm{~B}$ & $14-15 \mathrm{~B}$ & $14-15 \mathrm{~B}$ \\
\hline & & &
\end{tabular}

\section{Endotrombicula madagascariensis (Sambon, 1928)}

Fig. 2

1928 Schoengastia madagascariensis, Sambon, Ann. Trop. Med. Parasitol. 22: 121.

1954 Endotrombicula madagascariensis, Radford, Fieldiana 34 (28): 307.

Description. Larva $(n=15)$. Orange in colour when alive. All specimens engorged, range of idiosoma 450600 length and 320-420 width $(\mathrm{n}=5$, not mounted or squeezed). Gnathosoma (Fig. 2C): Cheliceral claw with three prominent teeth dorsally, outer side laterally with prominent tooth directed backwardly. Dorsolaterally at anterior part of gnathosoma a pair of smooth, pointed deutorostrals (os) (23-26), ventrally near base of gnathosoma paired tritorostrals (bs) (30-35), each with 7-9 setules. No protorostrals and no supracoxal setae seen. One setulose seta each on palp femur (19-28), palp genu (10-14). Palp tibia with two smooth setae dorsally plus seta with $4-5$ prominent setules laterally. Odontus distally divided into two lateral claws and weaker median claw. Palp tarsus with 7 setulose setae, proximal solenidium $\omega$ and distal eupathidium $\zeta$. Idiosoma, dorsum (Fig. 2A): Scutum (Fig. 2B) pentagonal, paired AL and PL setae serrate, unpaired AM almost smooth. Sensilla smooth, distally globular (diameter 14-15). Laterally of scutum two pairs of eyes (lens 8-10 in diameter); each pair on common ovoid sclerite $(12-14 \times 23-$
30). Posterior to scutum 30 barbed setae (length 35-50) arranged in rows: $\mathrm{C}\left(\mathrm{c}_{1-5}\right), \mathrm{D}\left(\mathrm{d}_{1-3}\right), \mathrm{E}\left(\mathrm{e}_{1-3}\right), \mathrm{F}\left(\mathrm{f}_{1-3}\right), \mathrm{H}$ $\left(\mathrm{h}_{1}\right)$. Idiosoma, venter (Fig. 2A): Paired Claparède's organs laterally between coxae I/II. Coxa I with $1 \mathrm{~b}$ (3134) setulose, 1a (25-28) barbed and located medially outside coxal plate. Coxa II with barbed $2 b(41-44)$, coxa III with setulose $3 \mathrm{~b}$ (38-41), intercoxal seta $3 \mathrm{a}$ (31-34) barbed. Posterior to level of coxae III about 24 setae (length 24-45) around the unsclerotized anal opening (about 20 long). Legs (Fig. 2D): Segmentation formula: 7-7-7. Pretarsus of legs I-III each with paired claws and claw-like empodium; claws and empodium smooth, without splinters. Setal patterns in Table 1, morphometric data in Table 2.

Postlarval instars unknown.

H o s t s : Anura. Mantellidae: Aglyptodactylus madagascariensis (Duméril) (1 frog, 14 mites, Andasibe, Madagascar); Mantidactylus brevipalmatus Ahl (5, 24, Ankaratra Massif, Madagascar). Data on slides of BMNH material (see below): Mantidactylus luteus (Madagascar) [now Gephyromantis luteus (Methuen et Hewitt) according to Frost et al. 2006].

Material used for redescription: Specimens on slides from BMNH (holotype of E. madagascariensis and specimens 1952-9-24-143, 1952-9-24-140, 1952-9-24138 and 1952-9-24-136) were not suitable for redescription because insufficiently cleared; moreover, their legs are partly lost or shrivelled. Therefore the present redescription is based on 15 larvae removed from A. madagascariensis 

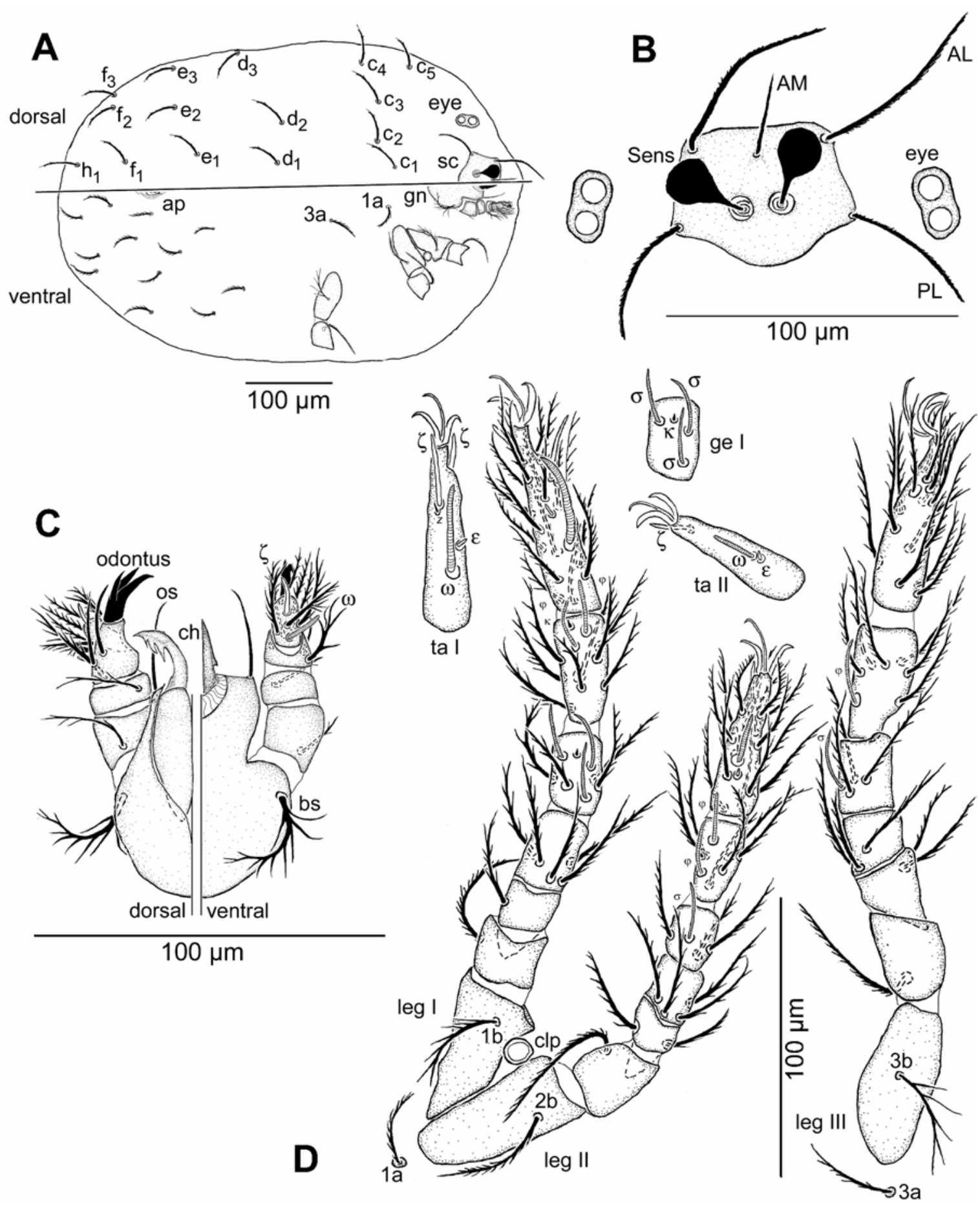

Fig. 2. Endotrombicula madagascariensis, larva. A - Dorsal and ventral view of a fully engorged larva, legs omitted beyond trochanter; ap - anal pore; gn - gnathosoma; sc - scutum. B - Scutum and ocular sclerite. C - Gnathosoma, dorsal (left) and ventral (right) view. D - Legs. Only specialised setae shown in details of tarsus I (ta I), genu I (ge I) and tarsus II (ta II). For abbreviations see Fig. 1 and text.

and M. brevipalmatus. Vouchers deposited at BMNH: specimen PL050121D8 ex A. madagascariensis, Andasibe, Madagascar, $18^{\circ} 55^{\prime} 54 \mathrm{~S}, 48^{\circ} 25^{\prime} 44 \mathrm{E}, 988 \mathrm{~m}$ above sea level, 21 January 2005; specimen PL060216D1 ex M. brevipalmatus, Ankaratra Massif on a plateau below Tsiafajavona mountain, $19^{\circ} 20^{\prime} \mathrm{S}, 47^{\circ} 14^{\prime} \mathrm{E}, 2,380 \mathrm{~m}, 16$ February 2006. Vouchers deposited at ZMH: specimen PL060216D7 ex M. brevipalmatus, Ankaratra Massif, $19^{\circ} 20^{\prime} \mathrm{S}, 4^{\circ} 14^{\prime} \mathrm{E}$, 16 February 2006; specimen PL050115H1 ex M. brevipalmatus, same location, 15 January 2005 . Vouchers deposited at PaU: specimens PL060216D4a, b ex M. brevipalmatus, Ankaratra Massif, $19^{\circ} 20^{\prime} \mathrm{S}, 47^{\circ} 14^{\prime} \mathrm{E}, 16$ February 2006, no. PAU 2019. 
Table 2. Standard measurements (in $\mu \mathrm{m}$ ) of Endotrombicula larvae.

\begin{tabular}{llccc}
\hline \multirow{5}{*}{ Gnathosoma } & Digitus of chelicera & $\begin{array}{c}\text { E. pillersi } \\
(\mathrm{n}=15)\end{array}$ & $\begin{array}{c}\text { E. madagascariensis } \\
(\mathrm{n}=10)\end{array}$ & $\begin{array}{c}\text { E. ptychadenae sp. } \mathrm{n} . \\
(\mathrm{n}=9)\end{array}$ \\
& Palp femur & $19-28$ & $23-33$ & $28-36$ \\
& Palp genu & $9-16$ & $19-28$ & $25-35$ \\
& Palp tibia (excl. odontus) & $14-16$ & $10-14$ & $10-14$ \\
& Odontus & $14-20$ & $18-19$ & $15-20$ \\
& Palp tarsus & $14-15$ & $12-14$ & $14-20$ \\
Scutum & Length & $45-53$ & $46-57$ & $15-16$ \\
& Width & $61-67$ & $64-70$ & $51-55$ \\
& AM & $21-29$ & $26-38$ & $70-75$ \\
& AL & $50-67$ & $60-79$ & $30-40$ \\
& Distance AL-AL & $40-46$ & $43-46$ & $62-66$ \\
& PL & $44-52$ & $52-62$ & $52-60$ \\
& Distance PL-PL & $55-61$ & $61-64$ & $76-82$ \\
& Sensillum (Sens) & $25-30$ & $27-35$ & $54-66$ \\
& Distance Sens-Sens & $12-15$ & $10-13$ & $29-30$ \\
& Coxa I & $42-47$ & $52-58$ & $14-16$ \\
& Trochanter I & $20-25$ & $21-28$ & $46-60$ \\
& Femur* I & $46-60$ & $45-57$ & $26-28$ \\
& Genu I & $28-31$ & $27-29$ & $57-65$ \\
& Tibia I & $35-40$ & $37-40$ & $35-39$ \\
Leg II & Tarsus I & $62-69$ & $68-71$ & $45-48$ \\
& Coxa II & $40-52$ & $55-60$ & $70-83$ \\
& Trochanter II & $18-23$ & $26-29$ & $52-55$ \\
& Femur* II & $42-49$ & $33-46$ & $20-29$ \\
& Genu II & $18-21$ & $20-22$ & $36-54$ \\
& Tibia II & $28-34$ & $29-36$ & $24-27$ \\
& Tarsus II & $42-50$ & $50-55$ & $35-40$ \\
& Coxa III & $40-46$ & $56-59$ & $53-62$ \\
& Trochanter III & $20-26$ & $32-34$ & $53-55$ \\
& Femur* III & $42-47$ & $38-53$ & $34-35$ \\
& Genu III & $21-24$ & $23-26$ & $44-62$ \\
& Tibia III & $31-40$ & $35-42$ & $30-33$ \\
& Tarsus III & $52-58$ & $60-65$ & $73-48$ \\
& & & & $75-80$ \\
\hline
\end{tabular}

* - basi- plus telofemur.

\section{Endotrombicula ptychadenae sp. $\mathrm{n}$.}

Fig. 3

Description. Larva $(n=12)$. All mite larvae engorged, of orange colouration when alive. Idiosoma 600-700 long and 420-480 wide $(n=10$, not mounted or squeezed). Gnathosoma (Fig. 3B): Cheliceral claw with three prominent teeth dorsally, outer side laterally with prominent tooth directed backwardly. Dorsolaterally at anterior part of gnathosoma paired deutorostrals (os) (24-26) smooth, pointed; ventrally near base of gnathosoma paired tritorostrals (bs) (35-45), each with 7-11 setules. No protorostrals and no supracoxal setae seen. Seta on palp femur peg-like (4-6); seta on palp genu long (27-30), serrate. Palp tibia with one smooth and two setulose setae. Odontus distally divided into two lateral claws and weaker median claw. Palp tarsus with 7 setulose setae, proximal solenidium $\omega$ and distal eupathidium $\zeta$. Idiosoma, dorsum: Scutum (Fig. 3A) pentagonal; paired AL, PL serrate, unpaired AM with few setules. Sensilla smooth, distally globular (diameter 14-16). Laterally of scutum paired ocular sclerites $(13 \times 25)$, each with two eyes (lenses each 10 in diameter). Posterior to scutum 30 barbed setae (length 50-65) arranged in arranged in rows: C ( $\left.\mathrm{c}_{1-5}\right), \mathrm{D}$ $\left(\mathrm{d}_{1-3}\right), \mathrm{E}\left(\mathrm{e}_{1-3}\right), \mathrm{F}\left(\mathrm{f}_{1-3}\right), \mathrm{H}\left(\mathrm{h}_{1}\right)$. Idiosoma, venter: Paired Claparède's organs laterally between coxae I/II. Coxa I with setulose 1b (40-50). Setulose 1a (40-48) located medially outside coxal plate. Coxa II with serrate $2 \mathrm{~b}$ (40-50). Coxa III with setulose 3b (34-44), serrate intercoxal setae 3a (30-35) medially of coxae III. Posterior to level of coxae III about 20 setae (length 35-45) around the unsclerotized anal opening (about 10-20 long). Legs (Fig. 3C): Segmentation formula: 7-7-7. Pretarsus of legs I-III each with paired claws and clawlike empodium; claws and empodium smooth, without splinters. Setal patterns in Table 1, morphometric data in Table 2.

Postlarval instars unknown.

H o s t s : Anura. Ptychadenidae: Ptychadena mascareniensis (Duméril et Bibron) (9 frogs, 28 mite larvae, Ambatolampy, Madagascar).

$\mathrm{T}$ y $\mathrm{p}$ e $\mathrm{d}$ a $\mathrm{t}$ a : Holotype deposited at BMNH (accession number BMNH(E) 2007-4): specimen PL060215F3 ex Ptychadena mascareniensis (ZCMV 2723-2724 and 27262732), swamp and rice fields near Ambatolampy, Madagascar, $19^{\circ} 22^{\prime} \mathrm{S}, 4^{\circ} 26^{\prime} \mathrm{E}, 1,600 \mathrm{~m}$ above sea level, 14-16 February 2006. Paratypes with same host and loca- 


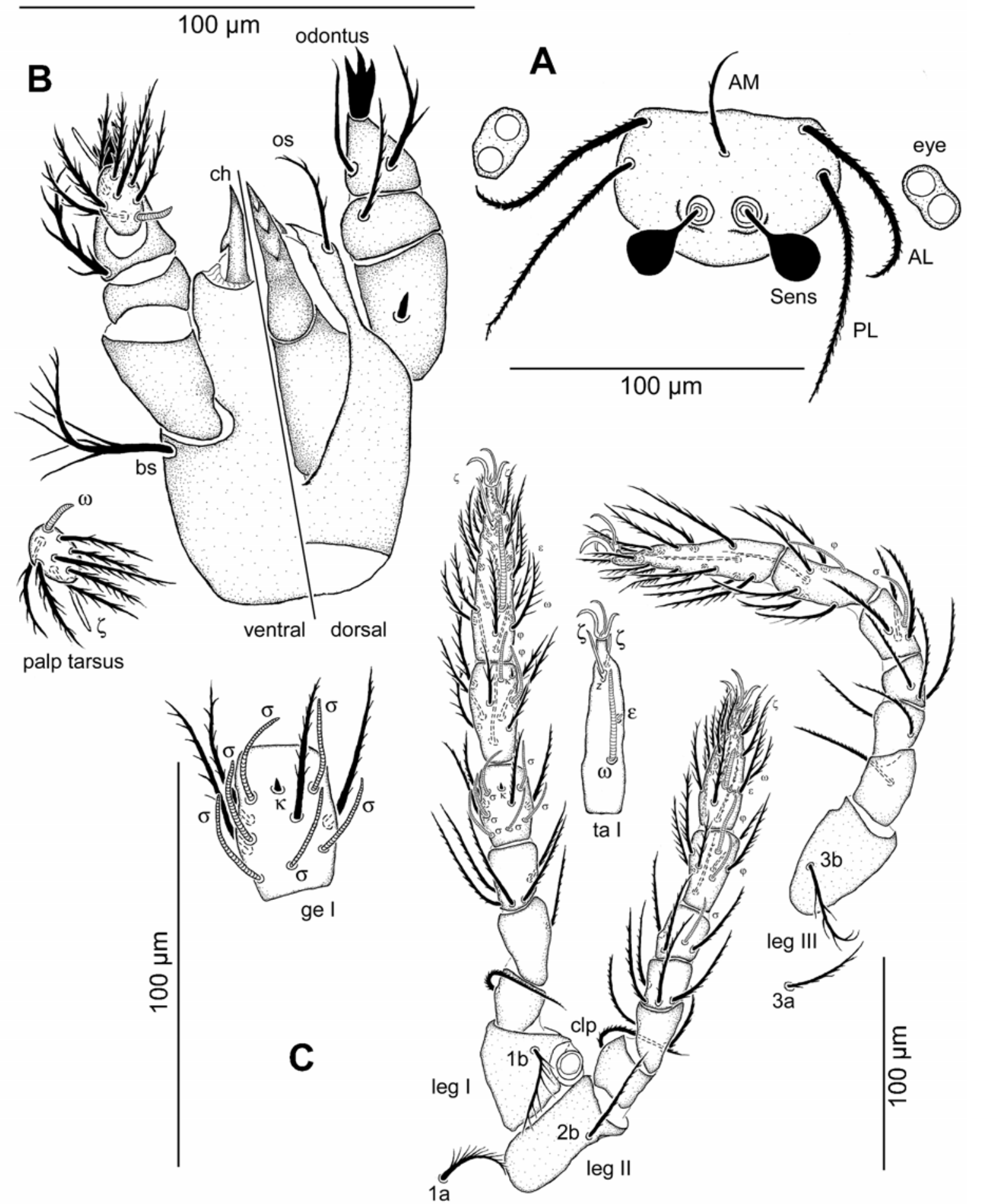

Fig. 3. Endotrombicula ptychadenae sp. n., larva. A - Scutum and ocular sclerite. B - Gnathosoma in dorsal (right) and ventral (left) view. Detail of palp tarsus in ventral view. C - Legs. Only specialised setae shown in details of tarsus I (ta I). Scale on the left refers exclusively to detail of genu I (ge I). For abbreviations see Fig. 1 and text.

tion data deposited at BMNH (PL060214A5), ZMH (PL060215F6, PL060214A4), PaU (PL060214A1) (no. PAU 2020) and at the senior author's collection (PL060215F4, PL060215F1).

E t y $\mathrm{m}$ o 1 o g y : The specific epithet derives from the generic name of the host.

\section{Host-parasite associations}

About two thirds of the known frog species in Taï National Park, Ivory Coast, were examined throughout two years 1999, 2000 (Rödel and Ernst 2004). Of 4,329 frogs representing 41 different species, 298 frogs of 


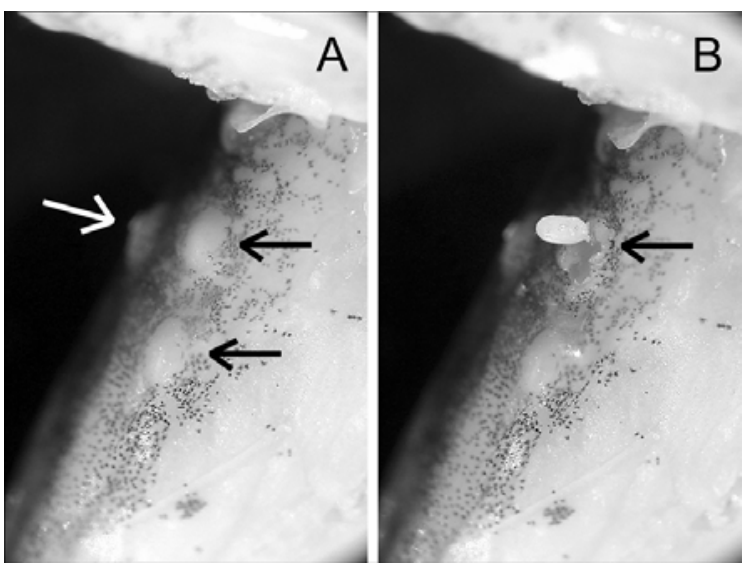

Fig. 4. Phrynobatrachus alleni parasitized by Endotrombicula pillersi larvae. A - Capsules (arrows) with subcutaneous $E$. pillersi at thigh of left hind leg of $P$. alleni, ventral view. B - As in A, but one mite partly pulled out (arrow).

five Phrynobatrachus species ( $P$. accraensis, $P$. alleni, $P$. francisci, $P$. plicatus, $P$. villersi) and of one Petropedetes ( $P$. natator) were found to be parasitized with 1,172 E. pillersi larvae. Most heavily infested was $P$. alleni (235 infested out of 1,183 examined). No obvious change in infection rates was found in subsequent years. One single Ptychadena aequiplicata infested with one Endotrombicula mite (among 75 further P. aequiplicata individuals which carried no mites) unfortunately was not collected and the mite could not be determined to species level. All infested host species except for the more riparian Petropedetes were leaf litter frogs; neither arboreal nor strictly aquatic frogs were found infested. Terrestrial leaf litter frogs of the family Arthroleptidae shared the habitat with the infested species in Taï National Park; however, no arthroleptid was found parasitized by Endotrombicula larvae.

At all three localities investigated on Madagascar, numerous frog species occur. Andasibe is the speciesrichest area in Madagascar, with more than 100 frog species recorded (F. Glaw and M. Vences, unpublished data). A single Aglyptodactylus madagascariensis was infested with E. madagascariensis, and although we did not systematically survey all species for Endotrombicula spp., it is remarkable that these parasites were not recorded more frequently. At Ankaratra, we screened over 200 specimens of altogether seven microsympatric frog species, especially of Mantidactylus curtus and $M$. alutus, but found no evidence for Endotrombicula in any species except for $M$. brevipalmatus. Of four $M$. brevipalmatus collected in 2005 one was infested with mites; of five specimens collected in 2006, each frog was infested.

No overlap was found in host resources used by the Endotrombicula species investigated. The type of parasitic association was similar in the three species observed; all mite larvae were found subcutaneous. No strict site specificity was obvious; however, all mites infested body parts of the host which likely touch the ground, predominantly the legs. Prevalence was up to $50 \%$ at a particular locality (only samples with more than five potential hosts considered). Intensity varied considerably; on some frogs only a single mite larva was found, maximum numbers were 31 (E. pillersi on Petropedetes natator), 14 (E. madagascariensis on Aglyptodactylus madagascariensis) and 10 (E. ptychadenae on Ptychadena mascareniensis), respectively. In heavily infested hosts, mite larvae usually were at different stages of engorgement.

\section{DISCUSSION}

\section{Taxonomy}

The genus Endotrombicula Ewing, 1931 is known from larvae only and originally included the type species E. penetrans Ewing, 1931. Schoengastia lynni Ewing, 1942, collected from a frog in Jamaica, was transferred to Endotrombicula by Wharton and Fuller (1952). However, this proposal was not followed by subsequent investigators, due to the poor quality of the description and the loss of type material (W.C. Welbourn, pers. comm.). Radford (1954) described Endotrombicula bufonica Radford, 1954 and transferred two species originally described as Schoengastia Oudemans, 1910 to Endotrombicula - E. pillersi and E. madagascariensis. Based on each a single specimen, without any data about designation and deposition of types, Vercammen-Grandjean (1958) described Endotrombicula barrosi Vercammen-Grandjean, 1958 and E. rana Vercammen-Grandjean, 1958 from African frogs.

Published descriptions are incomplete and do not allow unambiguous identification of species. In case of $E$. penetrans, E. bufonica, E. barrosi and E. rana our attempts to examine type material failed. In particular a proper determination of $E$. penetrans is not possible based on the published data. Endotrombicula bufonica, E. barrosi and E. rana are discernible (Table 3); however, characters such as differing numbers of leg segments with partially fused basi- and telofemur (6! in Table 3 ) in E. barrosi and E. rana need evaluation when material is available.

Examination of the types of E. pillersi as well as of E. madagascariensis revealed that specimens are partially fragmented and not suited for redescription. However, characters seen in types and other material from BMNH suggest that material sampled in various parts of West Africa in 1992-2005 (comprising the material listed in Spieler and Linsenmair 1999) includes only $E$. pillersi, and that the mites collected in Madagascar (2005, 2006) from Aglyptodactylus madagascariensis and Mantidactylus brevipalmatus belong to E. madagascariensis. Characters of E. ptychadenae unambiguously demand its inclusion into Endotrombicula; apart from the endoparasitic life-style in anuran amphibians 
this is derived in particular from the specific form of chelicerae and of sensilla. It differs from other $E n$ dotrombicula species in the form of the seta on palp femur, the number of solenidia on genu I and other characters listed in Table 3. Comparisons with other Parasitengona such as Johnstoniana George, 1909, for which biological data provide convincing causal reasoning for (bio-) species hypotheses (Wohltmann et al. 2004), show that such morphological differences constitute reasonable indications of separated species.

\section{Host-parasite associations}

In general, our data confirm earlier results (Sambon 1928, Spieler and Linsenmair 1999). In an extensive study Spieler and Linsenmair (1999) investigated prevalence and number of mites per host for E. pillersi. They found up to $90 \%$ of the Phrynobatrachus francisci sampled at a particular location and time infested by $E$. pillersi, with a maximum of 227 specimens on a single frog. Other anurans occurring sympatrically (33 species, including other Phrynobatrachus species, Rödel and Spieler 2000) were not parasitized by Endotrombicula mites. However, the hypothesis of Spieler and Linsenmair (1999) about E. pillersi being a species-specific parasite of the West African savanna frog $P$. francisci is too strict. Present data show that other species of Phrynobatrachus and even one species of Petropedetes also serve as hosts. Likewise, host specificity of $E$. madagascariensis seems restricted to a few but not single host species and includes frogs of the genera Aglyptodactylus, Mantidactylus and Gephyromantis. Comparison with other Parasitengona in general shows that species-specific parasite-host association is exceptional (Wohltmann 2000). Restricted host ranges in the field usually result from the limited presence and accessibility of hosts at a particular location and time (Nadchatram 2006). In Hannemania Oudemans, 1911, trombiculids parasitizing American anurans, it is evident that different species inhabiting different microhabitats do use the same host range (Wohltmann et al. 2006b). In Madagascar, it is remarkable that all three frog species known to be parasitized spend much time in terrestrial habitats. Other common anurans in this area are either more strictly aquatic (e.g., Mantidactylus curtus) or arboreal (e.g., Heterixalus betsileo). Assuming that oviposition and egg development of Endotrombicula species take place at edaphic conditions, as known for other trombiculids and trombidioid Parasitengona in general (Wohltmann 2000, Nadchatram 2006, and references therein), host-seeking larvae will be present in the leaf litter layer. Such behaviour would explain our observation that neither arboreal nor strictly aquatic frogs are used as hosts by Endotrombicula mites.

With regard to the different stages of engorgement of Endotrombicula larvae observed in an individual host, we assume that hosts may experience repeated invasion by mite larvae. Data on the duration of the parasitic

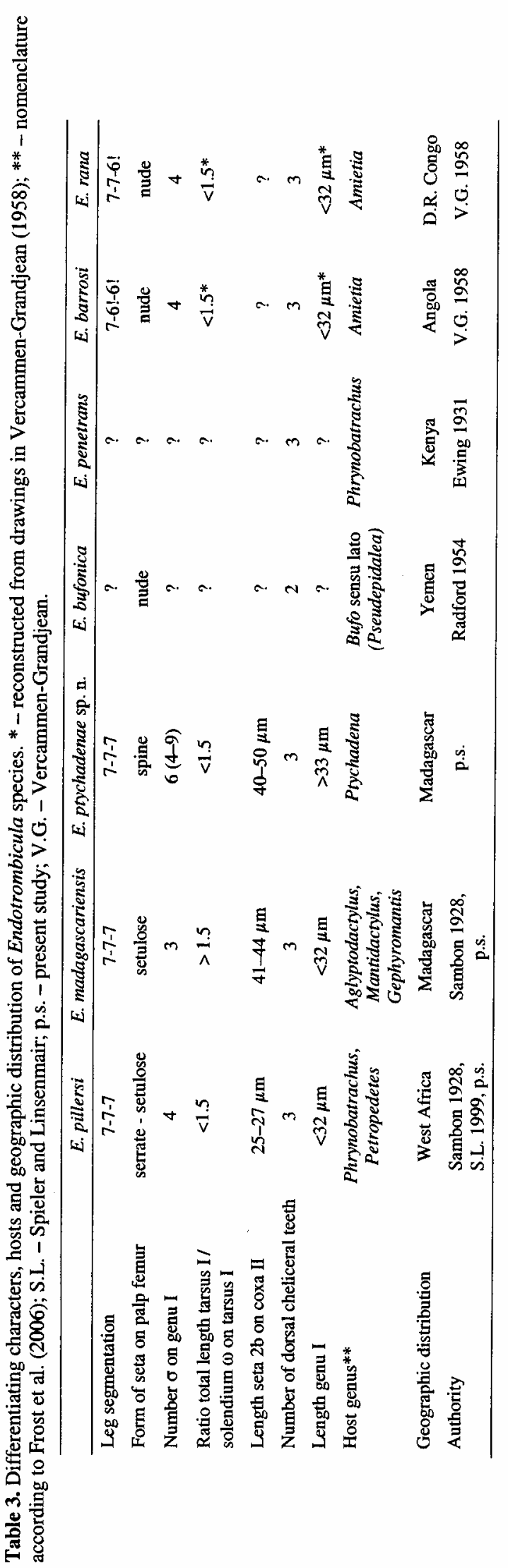


phase and its impact on hosts are still fragmentary. Spieler and Linsenmair (1999) reported that frogs carrying less than $100 \mathrm{E}$. pillersi had no visible pathological symptoms, even when hosts were kept in terrariums for up to three years. During that period no larvae left the host. Hyland (1961) induced detachment of Hannemania larvae from legs of infested Lithobates sphenocephalus by ligation. However, without such artificial intervention the larvae remained on the host for up to six months in the laboratory. This is much longer than the time needed to complete engorgement (Hyland 1961). It seems likely that attached larvae of Hannemania and of Endotrombicula need particular environmental stimuli (possibly transmitted via the host) to terminate the parasitic phase.

\section{Biogeography}

Madagascar is inhabited by a species-rich anuran fauna. Almost all species are endemic, with the endemic family Mantellidae displaying highest diversity concerning ecological demands, reproductive diversity and species numbers. The sister group of mantellids are the Asian rhacophorids. This reflects both the isolated position of Madagascar and its geological origin with last land connections to India about 88 million years ago (Bossuyt and Milinkovitch 2001, Briggs 2003). One might expect that Endotrombicula mites accompanied their hosts during their geological journey. However, the known species of Endotrombicula outside Madagascar inhabit Africa and the Arabian Peninsula (Table 3). No Endotrombicula spp. have been reported from India or neighbouring Asian regions. Actually no Trombiculidae parasitizing anurans are known from this area, although Anura (e.g., Daniels 2005) and Trombiculidae (Stan Fernandes and Kulkarni 2003, and references therein) are observed since decades. The nearest geographical report of Trombiculidae parasitizing anurans is from Malaysia (Audy and Nadchatram 1957) and concerns Vercammenia Audy et Nadchatram, 1957. With regard to the origin of Endotrombicula spp. in Madagascar it seems thus conceivable that parasites invaded the island from the African continent later in geological history when several subsequent anuran colonisations from the African continent occurred by overseas dispersal. Possible candidates were hyperoliid frogs, which were estimated to have arrived 19-30 million years ago (Vences et al. 2003), or Ptychadena mascareniensis which probably originated by a much more recent colonisation (Vences et al. 2004). The latter alternative is supported by the fact that species of Ptychadena are widespread over most of Africa (Vences et al. 2004). In this admittedly hypothetical scenario, the ancestor of Ptychadena mascareniensis could have carried Endotrombicula mites to Madagascar, where the mites invaded frogs of the family Mantellidae and gave rise to the species E. madagascariensis.

Acknowledgements. We express our thanks to Dr. Anne Baker (BMNH) for sending types and other material of Endotrombicula. Vladimír Bukva, Cal Welbourn and two anonymous referees provided valuable advices on earlier drafts of the manuscript. The University of Bremen provided equipment and working space for the study of mites. The work in Madagascar was made possible by collaboration accords with the Département de Biologie Animale of the Université d'Antananarivo, and with the Asociation Nationale pour la Gestion des Aires Protegées ANGAP. We thank the Malagasy authorities for the collection and export permits.

\section{REFERENCES}

AUDY J.R., NADCHATRAM M. 1957: Malaysian parasites - XIX Vercammenia, new genus of chiggers hypodermal in Amphibia (Acarina, Trombiculidae). Stud. Inst. Med. Res. Malaysia 28: 95-102.

Bentz S., Leroy S., Du Preez L.H., MariauX J., VAuCher C., VERNEAU O. 2001: Origin and evolution of African Polystoma (Monogenea: Polystomatidae) assessed by molecular methods. Int. J. Parasitol. 31: 697-705.

BossuYT F., MiLINKOVITCH M.C. 2001: Amphibians as indicators of Early Tertiary 'out-of India' dispersal of vertebrates. Science 292: 93-95.

BRIGGS J.C. 2003: The biogeographic and tectonic history of India. J. Biogeogr. 30: 381-388.

DANIELS R.J.R. 2005: Amphibians of Peninsular India. Universities Press (India), Hyderabad, 268 pp.

EWING H.E. 1931: A catalogue of the Trombiculinae, or chigger mites, of the new world with new genera and species and a key to the genera. Proc. U. S. Nat. Mus. 80: 1-19.

Frost D.R., Grant T., Faivovich J., Bain R.H., HaAs A., HADDAD C.F.B., DE SÁ R.O., CHANNING A., WILKINSON M., DONNEllan S.C., RAXWORTHY C.J., CAMPBEll J.A., Blotto B.L., Moler P., Drewes R.C., NusSbaum R.A., LYNCH J.D., GREEN D.M., WHEELER W.C. 2006: The amphibian tree of life. Bull. Am. Mus. Nat. Hist. 297: 1-370.
HYLAND K.E. 1961: Parasitic phase of chigger mite, Hannemania hegeneri, on experimentally infested amphibians. Exp. Parasitol. 11: 212-225.

Measey G.J., Vences M., Drewes R.C., Chiari Y., Melo M., BOURLES B. 2006: Freshwater paths into the ocean: molecular phylogeny of the frog Ptychadena newtoni gives insights into amphibian colonization of oceanic islands. J. Biogeogr. 34: 7-20.

NADCHATRAM M. 2006: A review of endoparasitic acarines of Malaysia with special reference to novel endoparasitism of mites in amphibious sea snakes and supplementary notes on ecology of chiggers. Trop. Biomed. 23: 1-22.

POYNTON J.C. 1999: Distribution of amphibians in Sub-Saharan Africa, Madagascar, and Seychelles. In: W.E. Duellman (Ed.), Patterns of Distribution of Amphibians, a Global Perspective. Johns Hopkins University Press, Baltimore, pp. 483-539.

RADFORD C.D. 1954: Some mites of Yemen. Fieldiana 34 (28): 295-313.

RoBAUX P. 1974: Recherches sur le développement et la biologie des acariens 'Thrombidiidae'. Mém. Mus. Natl. Hist. Nat. Paris (n.s.), Série A, 85: 1-186.

RÖDEL M.-O., ERNST R. 2004: Measuring and monitoring amphibian diversity in tropical forests. I. An evaluation of meth- 
ods with recommendations for standardization. Ecotropica 10: $1-14$.

RÖDEL M.-O., SPIELER M. 2000: Trilingual keys to the savannahanurans of the Comoé National Park, Ivory Coast. Stutt. Beitr. Naturkd. (A) 620: 1-31.

ROELANTS K., BOSSUYT F. 2005: Archaeobatrachian paraphyly and Pangaean diversification of crown-group frogs. Syst. Biol. 54: 111-126.

SAMBON L.W. 1928: The parasitic acariens of animals and the part they play in the causation of eruptive fevers and other diseases of man. Ann. Trop. Med. Parasitol. 22: 67-132.

SPIELER M., LINSENMAIR K.E. 1999: The larval mite Endotrombicula pillersi (Acarina: Trombiculidae) as a species-specific parasite of a West African savannah frog (Phrynobatrachus francisci). Am. Midl. Nat. 142: 152-161.

STAN FERNANDES S.J., KULKARNI S.M. 2003: Studies on the trombiculid mite fauna of India. Rec. Zool. Surv. India Occas. Pap. 212: 1-539.

VENCES M., KoSUCH J., RÖDEL M.-O., LÖTTERS S., CHANNING A., GLAW F., BÖHME W. 2004: Phylogeography of Ptychadena mascareniensis suggests transoceanic dispersal in a widespread African-Malagasy frog lineage. J. Biogeogr. 31: 593-601.
Vences M., Vieites D.R., Glaw F., BRinKManN H., KOSUCH J., Veith M., Meyer A. 2003: Multiple overseas dispersal in amphibians. Proc. R. Soc. (B) 270: 2435-2442.

VERCAMMEN-GRANDJEAN P.H. 1958: Revue des Schoengastia centrafricains et remaniements divers de cet important genre (Acarina - Trombiculidae). Ann. Parasitol. Hum. Comp. 33: 619-670.

WHARTON G.W., FULLER H.S. 1952: A manual of the chiggers. Mem. Entomol. Soc. Wash. 4: 1-185.

Wohltmann A. 2000: The evolution of life histories in Parasitengona (Acari: Prostigmata). Acarologia 41: 145-204.

WOHLTMANN A., GABRYŚ G., MAূKOL J. 2006a: Terrestrial Parasitengona inhabiting transient biotopes. In: R. Gerecke (Ed.), Süßwasserfauna Mitteleuropas, Vol. 7/2-1, Chelicerata, Acari I. (2007). Spektrum Elsevier, München, pp. 158-240.

WOHLTMANN A., KÖHLER J., MARTIN P. 2006b: Endoparasitic mite infections of anuran amphibians from Bolivian montane rain forests, with descriptions of two new Hannemania species (Acari: Parasitengona: Trombiculidae: Leeuwenhoekiinae). Org. Divers. Evol. 6: 141-150.

WOHLTMANN A., MĄKOL J., GABRYŚ G. 2004: A revision of European Johnstonianinae (Acari: Prostigmata: Parasitengona: Trombidioidea). Ann. Zool. 54: 595-630.

Accepted 15 February 2007 